\title{
Stress among nurses: an examination of salivary cortisol levels on work and day off
}

\author{
ESTRESSE EM ENFERMEIROS: O USO DO CORTISOL SALIVAR NO DIA DE TRABALHO \\ E DE FOLGA
}

\section{ESTRÉS EN ENFERMERAS: LA UTILIZACIÓN DEL CORTISOL SALIVAL DURANTE EL DÍA DE TRABAJO Y DE DESCANSO}

\author{
Maria Cecília Pires da Rocha', Milva Maria Figueiredo De Martino², \\ Dora Maria Grassi-Kassisse ${ }^{3}$, Aglécio Luiz de Souza ${ }^{4}$
}

\begin{abstract}
The present study evaluates the use of salivary cortisol concentration as a physiological index of the stress level among nurses on their work day and day off and correlates it with the questionnaire used to measure occupational stress in nurses (Inventário de Estresse em Enfermeiros IEE). This is a comparative, cross-sectional descriptive study in which sociodemographic data, IEE results and salivary cortisol levels were used. Fifty-seven nurses participated in the study $(80.7 \%$ females and a mean age of 37.1 years old). The IEE average score was 124.5. The average cortisol level was $564.1 \mathrm{ng} / \mathrm{m}$ on work day and $354.1 \mathrm{ng} / \mathrm{mL}$ on day off. Nurses who had double workdays presented high values of salivary cortisol during the work day $(638.1 \mathrm{ng} / \mathrm{mL})$. In conclusion, salivary cortisol identified the nurses' stress level, and differences were found between a work day and day off. On the nurses' day off, their salivary cortisol levels and stress scores were lower.
\end{abstract}

\section{DESCRIPTORS}

Stress, physiological

Hydrocortisone

Nursing

Occupational health

\section{RESUMO}

Este estudo avalia a concentração de cortisol salivar como índice fisiológico indicativo do grau de estresse em enfermeiros no dia de trabalho e de folga, correlacionando-o com o questionário do estresse (IEE). Pesquisa descritiva, comparativa e transversal em que foram utilizados dados sociodemográficos, o IEE e as dosagens de cortisol salivar. Participaram 57 enfermeiros $(80,7 \%$ do sexo feminino, média de 37,1 anos de idade). 0 escore médio do IEE foi 124,5. A concentração média de cortisol foi $564,1 \mathrm{ng} / \mathrm{mL}$ no dia de trabalho e de $354,1 \mathrm{ng} / \mathrm{mL}$ no de folga. Enfermeiros que realizavam dupla jornada de trabalho apresentaram valores na concentração de cortisol salivar superiores no dia de trabalho $(638,1 \mathrm{ng} / \mathrm{mL})$. Concluiu-se que a concentração salivar de cortisol identificou o grau de estresse de enfermeiros e a diferença obtida entre um dia de trabalho e de folga. No dia de folga, a concentração de cortisol salivar manteve valores inferiores, assim como o escore de estresse.

\section{DESCRITORES \\ Estresse fisiológico \\ Hidrocortisona \\ Enfermagem \\ Saúde do trabalhador}

\section{RESUMEN}

Este estudio analizó la concentración de cortisol salival como indicativo del índice fisiológico del estrés en enfermeras durante la jornada de trabajo y de descanso, correlacionándolo con el inventario de estrés (IEE). Investigación descriptiva, transversal y comparativa, donde se utilizaron datos socio-demográficos, el IEE y las dosis de cortisol salival. Participaron 57 enfermeras (80.7\% mujeres, con edad promedio de 37.1 años). La puntuación promedio de IEE fue de 124,5. La concentración media de cortisol fue de $564.1 \mathrm{ng} /$ $\mathrm{ml}$ en día de trabajo y de $354.1 \mathrm{ng} / \mathrm{mL}$ durante el descanso. Las enfermeras que realizaron doble jornada de trabajo, presentaron valores superiores en la concentración de cortisol salival durante la jornada de trabajo (638.1 $\mathrm{ng} / \mathrm{mL}$ ). Se concluyó que la concentración de cortisol en la saliva, identificó el grado de estrés de las enfermeras y la diferencia obtenida entre un día de trabajo y de descanso. En el día de descanso, la concentración de los valores de cortisol salival se mantuvo inferior, así como la puntuación de estrés.

\section{DESCRIPTORES \\ Estrés fisiológico \\ Hidrocortisona \\ Enfermería \\ Salud laboral}

*Extracted from the thesis "Análise do cortisol salivar como indicador do estresse e a relação com a qualidade do sono em enfermeiros", School of Nursing, University of Campinas, 2013. ${ }^{1}$ Nurse. Ph.D. School of Nursing, University of Campinas. CAPES scholarship holder. Campinas, SP, Brazil. piresdarocha@yahoo.com.br ${ }_{2}^{2}$ Nurse. Ph.D. Associate Professor, School of Nursing, University of Campinas. Campinas, SP, Brazil. milva@unicamp.br ${ }^{3}$ Pharmacist. Ph.D. Professor, Department of Structural and Functional Biology, Biology Institute, University of Campinas. Campinas, SP, Brazil. doramgk@unicamp.br ${ }^{4}$ Biologist. Master in Molecular and Functional Biology, Biology Institute at University of Campinas. Campinas, SP, Brazil. aglecios@hotmail.com 


\section{INTRODUCTION}

By nature, human beings seek to maintain a balance between internal forces and their organs so that their bodies can work in harmony. However, when that balance becomes altered by any stressor (that is, any situation that arouses a good or bad emotion), this imbalance becomes a source of stress. Stress can be positive, necessary and stimulating when it occurs within the physiological and psychological limits of an organism ${ }^{(1)}$; however, when stress exceeds an individual's capacity for adaptation, it can cause disease ${ }^{(2)}$.

The hypothalamus is the central nervous system structure responsible for regulating the organism's basic maintenance and survival functions. The hypothalamus acts on the autonomic nervous and endocrine systems, triggering organic responses in response to stimuli from both the external and internal environment. These responses allow the body to adapt to the changes that are produced by stressors ${ }^{(3)}$.

The hormone cortisol is produced by the adrenal glands, and its levels are increased during the last stages of sleep in humans to prepare the body to wake. The cortisol concentration is high at waking and decreases throughout the day, reaching lower concentrations before bedtime ${ }^{(4)}$. Cortisol is also considered an important marker of physiological stress ${ }^{(5)}$.

Nurses can present relevant changes in their health and their social and personal life in response to variations in cortisol levels. These changes in cortisol can be induced by everyday situations, such as occupational stress. The potentially stressful work situations that nurses are subjected to include unsanitary conditions, exhausting work hours and an intense work pace ${ }^{(6)}$.

The literature suggests that an individual's stress index should be assessed using both physiological markers, such as cortisol levels, and psychological indicators, such as questionnaires ${ }^{(7)}$. Questionnaires can be used to identify relevant stress issues in the organization of nurses' workplaces that are susceptible to intervention and improvement. Moreover, questionnaires show how each of the stressful situations experienced by individuals is actually identified as a stress source for the population under study, ${ }^{(8-9)}$ and they contribute to demystifying the notion that stress depends only on the person experiencing $i t^{(9)}$.

This study identified the presence of stress in nurses by examining the correlation between the analysis of salivary cortisol levels (a physiological index indicative of stress level) and the results of a questionnaire administered to the participants (a stress psychological assessment).

\section{METHOD}

This is a comparative, cross-sectional descriptive study with a quantitative approach that was conducted from October 2011 to March 2012. The study included 57 nurses in a high-complexity university hospital, which serves the Unified Health System (Sistema de Saúde -SUS) patients in the city of Campinas, São Paulo, Brazil. The hospital includes the following sectors: the Emergency Room (ER), Medical-Surgical Ward I (MSW-I) and Medical-Surgical Ward II (MSW-II).

The MSW I and II inpatient units assist patients who require complex and intensive nursing care in response to a lack of beds in the ICUs, which overloads the wards and mischaracterizes the workplace. The ER patients resemble those from the inpatient units. The hospital is a referral center for high-complexity admissions; however, the lack of beds in the other hospital sectors results in an overload of the ER, which consistently exceeds its maximum capacity.

All of the nurses who worked the morning, afternoon or evening shifts were invited to participate in the research. Nurses who were on medical leave, away from work or on vacation during the data collection period and those who did not return the questionnaires and the salivary cortisol samples on time were excluded from the study. Volunteers who collected their saliva erroneously and those who were using any medication that would influence the analysis reliability of cortisol levels (such as steroidal and nonsteroidal antiinflammatory drugs) were also excluded ${ }^{(10)}$.

Only nurses were included in this study to minimize the chances that differences in stress perception would occur because of performed at work ${ }^{(7)}$. The studied population has unique characteristics and consists of open-sector shift workers (closed sectors, such as the ICU and the Surgical Center, were excluded).

The participants returned the questionnaires during their work period. A deadline of 15 days was established for nurses who were unable to respond promptly the questionnaire but had agreed to participate in the study to facilitate the participants' cooperation. A date for the delivery of the Salivette ${ }^{\circledR}$ tubes used to collect saliva was also defined. The following research instruments were used: an identification form, the IEE questionnaire ${ }^{(8)}$ (Inventário de Estresse em Enfermeiros) and saliva samples collected in Salivette ${ }^{\circledR}$ tubes for salivary cortisol dosage.

\section{Identification form}

This form identified the nurses' sociodemographic data using personal information, such as gender, age and marital status and questions concerning professional experience (e.g., double workdays) and lifestyle (e.g., physical activities). 


\section{IEE questionnaire}

The IEE questionnaire, adapted and standardized for the Brazilian population, was designed to measure the stressors that the nurses in the workplace and their frequency in daily professional life. According to the authors, the inventory's construction was based on Cooper's theoretical definitions, in which stress is perceived by the individual as something negative as a result of the inability to deal with pressure sources at work ${ }^{(8)}$.

The IEE is a validated instrument and self-completed questionnaire developed for use with nurses ${ }^{(11)}$. It comprises 44 items in four domains that are answered using a Likert scale ranging from one to five, where (1) means never, (2) rarely, (3) sometimes, (4) often and (5) always. The higher the score, the greater the frequency with which the stressor is experienced. The IEE overall score can range from 44 to 220, and scores above 145 indicate the presence of stress. The value obtained in the questionnaire's validation showed good internal consistency, with a Cronbach's alpha of $0.89^{(8,11)}$.

The IEE's domains are the following: Interpersonal Relations (IR), Career Stressors Roles (CSR) and Intrinsic Job Factors (IJF). The IR domain addresses the frequency with which interpersonal relationships with other professionals, patients and family members are experienced as stressors by the worker; the CSR domain addresses the frequency of such stressors as the lack of recognition and professional autonomy. The IJF domain examines the frequency with which the nurse's experience performed functions, work hours and inadequate resources as stressors in the work environment.

\section{Salivary cortisol}

Saliva collection was performed by the nurse himself/ herself on two days and at four different times: upon waking, before lunch (between 12 p.m. and 1 p.m.), before dinner (between 7 p.m. and 8 p.m.) and before bedtime (between 10 p.m. and 11 p.m.). This procedure was performed by all of the participants on a work day and repeated on a day off.

The saliva samples were collected using high-absorption the cotton rolls included in the Salivette ${ }^{\circledR}$ tube. At each measurement time, the cotton roll was kept in the oral cavity for five minutes to collect the saliva samples at that time. The workers were instructed not to eat, drink, brush their teeth or smoke one hour before collecting the saliva, to wash their mouths with water after collection, to return the cotton roll to the respective Salivette ${ }^{\circledR}$ tube and keep the tube cool until the material was delivered to the main researcher.

The samples were processed at the Laboratory for the Study of Stress (Labeest) of the Institute of Biology, UNICAMP. The Salivette ${ }^{\circledR}$ tubes were centrifuged at 2,800 rpm for 20 minutes at $4^{\circ} \mathrm{C}$, and the supernatants were separated and stored at $-20^{\circ} \mathrm{C}$. Analyses were performed in duplicate using enzyme immunoassay (EIA; DBC ${ }^{\circledR}$ - Cortisol Saliva EIA Kit, Diagnostics Biochem Canada Inc.). A microplate reader capable of measuring absorbance at $450 \mathrm{~nm}$ was used to read the samples. The test protocol followed the provisions specified by the manufacturers.

Cortisol levels may vary depending on the type of assay and collection procedures used. In addition, cortisol levels varied among the studied population in particular because samples were collected during working hours, and the activities performed during the work shift vary in intensity, especially in terms of the presence of stressors.

Therefore, an acceptable limit of normal values for salivary cortisol was established based on the data collected. The saliva samples collected upon waking displayed an absolute range from 5 to $21.6 \mathrm{ng} / \mathrm{mL}$ according to the criteria established by the manufacturer $\left(D B C^{\circledR}\right)$. Regarding the assessment of physiological stress, the salivary cortisol levels were presented as an area under the curve (AUC). The AUC calculation is used to obtain information about various measures relating to a specific time period.

The study was approved by the Ethics Committee of the University of Campinas, Protocol No. 1181/2009. Prior to data collection, the individuals were informed about the research objectives, the voluntary nature of participation, the confidentiality assured for their responses and the requirement to complete and sign the Free and Clarified Consent Form.

The level of significance set for the statistical tests was $5 \%$, i.e., a $p$ value less than or equal to 0.05 indicated a statistically significant result $(p<0.05)$. The collected data were entered in Excel for Windows/98 (Microsoft Office 2003) and then transported to Statistical Analysis System (SAS) for Windows, Version 9.2 (SAS Institute Inc, 2002-2008, Cary, NC, USA). All statistical support was provided by the Statistical Office of the Research Commission, FCM, UNICAMP.

\section{RESULTS}

In this study, the IEE internal consistency analysis yielded a Cronbach's alpha coefficient of 0.942663. Table 1 shows the descriptive analysis of the IEE total score and salivary cortisol levels for work day and day off. The nurses' mean stress score (IEE) was 124.5. Regarding the AUC (area under the curve) values for salivary cortisol, the mean value on work day was $564.1 \mathrm{ng} / \mathrm{mL}$, and the mean value for day off was $354.1 \mathrm{ng} / \mathrm{mL}$. 
Table 1 - IEE total scores and salivary cortisol levels for nurses' work days and days off - Campinas, SP, 2011

\begin{tabular}{|c|c|c|c|c|c|c|}
\hline Variable** & $\mathbf{N}$ & Main & sd* & Minimum & Median & Maximum \\
\hline Total stress score & 57 & 124,5 & 26,9 & 63,0 & 115,0 & 183,0 \\
\hline Salivary cortisol (work day) & 54 & 355,6 & 140,8 & 99,3 & 382,4 & 665,2 \\
\hline
\end{tabular}

*sd: standard deviation; ** AUC (area under the curve).

Table 2 shows the sociodemographic characteristics of the nurses and the stress classification according to IEE scores.

Table 2 - General characteristics of the studied sample - Campinas, SP, 2011

\begin{tabular}{|c|c|c|}
\hline Variables & $\mathbf{N}$ & $\%$ \\
\hline \multicolumn{3}{|l|}{ Gender } \\
\hline Female & 46 & 80,7 \\
\hline Male & 11 & 19,3 \\
\hline \multicolumn{3}{|l|}{ Age group } \\
\hline 26 to 35 years & 30 & 52,6 \\
\hline 36 to 45 years & 16 & 28,1 \\
\hline 46 to 55 years & 10 & 17,5 \\
\hline 56 to 65 years & 1 & 1,8 \\
\hline \multicolumn{3}{|l|}{ Sectors } \\
\hline MSW-I & 23 & 40,4 \\
\hline MSW-II & 24 & 42,1 \\
\hline ER & 10 & 17,5 \\
\hline \multicolumn{3}{|c|}{ Double workday } \\
\hline Yes & 19 & 33,3 \\
\hline No & 38 & 66,7 \\
\hline \multicolumn{3}{|c|}{ Physical activity practice } \\
\hline Yes & 22 & 38,6 \\
\hline No & 35 & 61,4 \\
\hline \multicolumn{3}{|l|}{ IEE } \\
\hline Stressed & 14 & 24,6 \\
\hline Nonstressed & 43 & 75,4 \\
\hline Total & 57 & 100 \\
\hline
\end{tabular}

Figure 1 shows no significant correlation (Spearman's correlation coefficient, $r=0.14658 ; p=0.2902$ ) between the work day cortisol values and the nurses' stress scores. However, a positive ascendance in the correlation between the nurses' cortisol levels and stress scores was observed, showing a data tendency in the association between the proportional increase in the cortisol levels and the IEE stress scores.

According to Figure 2, no significant correlation (Spearman's correlation coefficient, $r=0.05289 ; p=$ 0.6960 ) was found between the mean cortisol levels on day off and the nurses' stress scores.

The results suggest that on the nurses' day off, stress is not evident, as both the salivary cortisol levels throughout the day and the IEE stress scores remained low.

Although the data displayed in Table 3 did not show statistically significant results, it suggests that on work days, the female nurses had higher salivary cortisol levels compared with the male nurses $(356.9 \mathrm{ng} / \mathrm{mL}$ versus $349.9 \mathrm{ng} / \mathrm{mL}$ ).
Correlation between cortisol and stress on work day

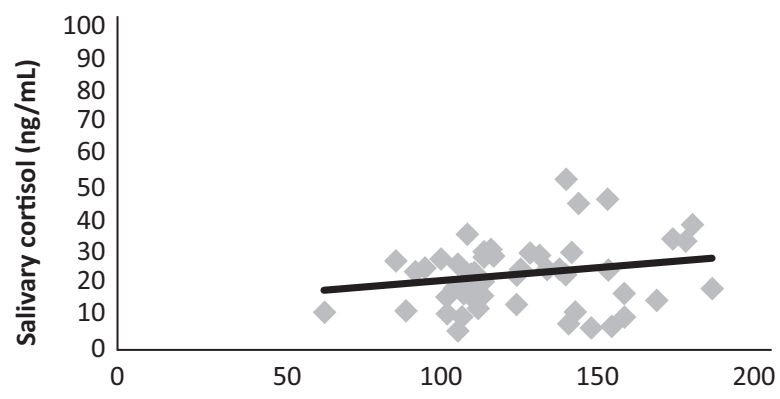

Stress score

Figure 1 - Correlation between the mean cortisol levels and the nurses' total stress scores for work day.

\section{Correlation between cortisol and stress on day off}

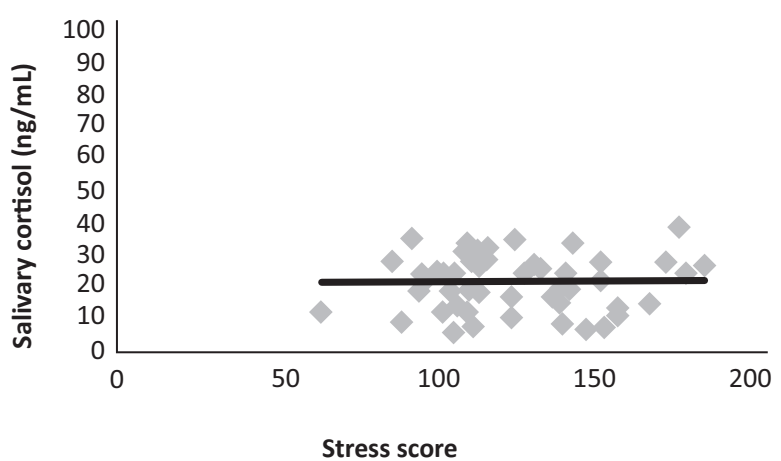

Figure 2 - Correlation between the mean cortisol levels and nurses' total stress scores on day off

The nurses who performed double workdays had higher salivary cortisol levels on work days compared with those who did not perform a double shift $(389.9 \mathrm{ng} / \mathrm{mL}$ versus $338.5 \mathrm{ng} / \mathrm{mL}$ ).

The nurses who engaged in physical activities showed lower cortisol levels during work day compared with nurses who did not exercise $(346.4 \mathrm{ng} / \mathrm{mL}$ versus $366.81 \mathrm{ng} /$ $\mathrm{mL}$ ). A comparison of cortisol levels among hospital sectors revealed that the nurses who worked at the MSW II on their work day had higher cortisol levels than did the nurses who worked at the MSW I and ER $(379.5 \mathrm{ng} / \mathrm{mL}$ > 
Table 3 - Comparison between variables and salivary cortisol levels in nurses for work days and days off - Campinas, SP, 2011

\begin{tabular}{|c|c|c|c|c|}
\hline \multirow{2}{*}{ Variables } & $\begin{array}{c}\text { Work day } \\
\text { salivary cortisol (ng/mL) }\end{array}$ & \multirow[t]{2}{*}{ p-value } & $\begin{array}{c}\text { Day off } \\
\text { salivary cortisol }(\mathrm{ng} / \mathrm{mL})\end{array}$ & \multirow[t]{2}{*}{ p-value } \\
\hline & Mean AUC ( \pm dp)* & & Mean AUC ( \pm dp)* & \\
\hline Gender** & & 0.9436 & & 0.7083 \\
\hline Female & $356,9( \pm 138,9)$ & & $351,7( \pm 132,3)$ & \\
\hline Male & $349,9( \pm 156,4)$ & & $364,5( \pm 120,2)$ & \\
\hline Double workday & & 0.2831 & & 0.2749 \\
\hline Yes & $389,9( \pm 153,7)$ & & $377,7( \pm 134,1)$ & \\
\hline No & $338,5( \pm 132,7)$ & & $342,4( \pm 126,7)$ & \\
\hline Physical activity practice ${ }^{* *}$ & & 0.4726 & & 0.9204 \\
\hline Yes & $346,4( \pm 127,7)$ & & $353,5( \pm 131,1)$ & \\
\hline No & $366,8( \pm 149,2)$ & & $359,9( \pm 128,0)$ & \\
\hline Sectors $* * *$ & & & & 0.6969 \\
\hline MSW-I & $355,0( \pm 149,6)$ & & $346,1( \pm 128,1)$ & \\
\hline MSW-II & $379,5( \pm 143,8)$ & & $373,9( \pm 114,4)$ & \\
\hline ER & $304,4( \pm 109,1)$ & & $325,4( \pm 167,5)$ & \\
\hline IEE *** & & & & 0.5445 \\
\hline Stressed & $339,1( \pm 188,2)$ & & $351,7( \pm 151,2)$ & \\
\hline Nonstressed & $359,8( \pm 128,4)$ & & $354,9( \pm 123,1)$ & \\
\hline
\end{tabular}

$355 \mathrm{ng} / \mathrm{mL}>304.4 \mathrm{ng} / \mathrm{mL}$ ). The difference between the nurses' salivary cortisol levels on work day and day off in the ER was insignificant; however, higher levels of salivary cortisol were observed on the day off $(325.4 \mathrm{ng} / \mathrm{mL}$ versus $304.4 \mathrm{ng} / \mathrm{mL}$ ).

\section{DISCUSSION}

The studied sample consisted of 57 individuals. The predominance of females in this study $(80.7 \%)$ is consistent with recent statistics provided by the Federal Board of Nursing (Conselho Federal de Enfermagem - COFEN) showing that $87.2 \%$ of Brazilian nurses are women and that the greatest concentration of these professionals is in the 26-to 35 -years-old age group ${ }^{(12)}$. Although gender differences in salivary cortisol levels and gender differences in psychological and physiological responses to stress have been reported in the literature ${ }^{(7)}$, no differences were found between the male and female nurses in the present study. However, salivary cortisol levels were higher among the women than among the men on work day; on day off, salivary cortisol levels were considerably lower among the men than among the women.

These findings are similar to the results of another study in which women had higher salivary cortisol levels than men did on work days ${ }^{(13)}$. The opposite relationship was observed on day off; then, salivary cortisol levels were higher for men than for women. The men's high levels of cortisol on their days off may suggest both excessive demands on days off and the results of the harm caused by work shifts ${ }^{(14)}$.

For women, the work day can be seen as a stressor, in contrast to the day off. Studies have shown that female nurses' satisfaction at work is lower than that of male nurses ${ }^{(15)}$. In addition, women are more affected by the characteristics of a bad work ${ }^{(16)}$ environment and feel the pressure to balance work and family life, caring for children and house work ${ }^{(17)}$, which can result in increased salivary cortisol levels when compared to men ${ }^{(18)}$.

In Brazil, it is common for nurses to work double shifts and receive low pay because of work shift scheduling ${ }^{(17)}$. When salivary cortisol levels are analyzed, the nurses who worked double shifts showed higher values on both work day and day off compared with nurses who had no other employment. However, the data showed that few participants in this study worked double shifts (33.3\%), most likely because of higher compensation, which is above the minimum wage for the professional class and in the state of São Paulo ${ }^{(11)}$.

The literature suggests that nurses are fully aware of the attitudes necessary for a healthy life; however, this knowledge is not applied to self-care ${ }^{(19)}$. On work days, the salivary cortisol values among nurses who were physically active were lower than those of nurses who were not active. These results suggest that physical activity may provide a protective effect against stress, reducing cortisol levels and the improving control of psychosocial responses to a particular stressor ${ }^{(20)}$.

Studies of physical activities and leisure show that such activities help individuals cope with situations that generate stress in everyday life by reducing musculoskeletal pain and physical fatigue and increasing energy to work ${ }^{(20)}$ and by reducing stress ${ }^{(21)}$.

Regarding comparisons among workplaces, the data point was the salivary cortisol values obtained on a work day. The nurses who worked at MSW II showed higher sa- 
livary cortisol values compared with nurses who worked at MSW I and the ER. The analysis of correlations between stress and nurses' workplaces is controversial in the literature. The sector in which the nurses perform their activities in the hospital may either induce stress or have no impact ${ }^{(11,22)}$. Working conditions and workers' personal characteristics differ among sectors and among institutions; therefore, it is impossible to state that one sector is more stressful than another.

At the MSW II admission unit, most patients require complex nursing care with infusions of vasoactive medications and constant monitoring of vital signs, which is believed to further generate stress in nurses. The correlation between workload and stress was observed in another study conducted with nurses ${ }^{(23)}$.

In the present study, the majority of the nurses did not show any stress (similar data were found in another study) $)^{(11)}$. The report and the perception of occupational stress have significant results when detailed instruments are used to assess stress ${ }^{(8)}$, and the stressful daily issues are perceived before and after the work day. A bias of this study may have been the use of a single instrument to measure occupational stress, as this instrument reflects the perceived stress during the month prior to data collection.

Given the limitations of instruments that assessing stress issues over the previous month, national studies have focused on the analysis and identification of stressors in nurses' occupational activities with the goal of mobilizing actions to reduce the stressors and providing effective coping strategies for dealing with stress at work ${ }^{(11-12)}$.

The literature shows that there is lack of organizational interventions to address occupational stress, which occurs mainly because of the institutional belief that employees are responsible for handling stress and the organization's inability to address $\mathrm{it}^{(24)}$.

Regardless of the instrument used to analyze stress in nurses' workplaces, high perceived rates of stress are not found ${ }^{(25)}$. National studies report that most professionals show mean rates and alertness ${ }^{(26)}$. Studies of nursing staff's stress levels are guided by the use of various instruments for data collection and use qualitative and quantitative approaches ${ }^{(9)}$. The adoption of a single instrument to measure occupational stress could contribute to more accurate and less contradictory results.

In the present study, individuals whose stress was assessed using a questionnaire (IEE) exhibited higher salivary cortisol levels during the work day than on the day off. However, the results were not significant. It is assumed that the individuals' responses when filling out an evaluation instrument are associated with individual differences in the backtracking stress perception that represent a disagreement with the obtained values at the time of salivary cortisol collection ${ }^{(7,10)}$. The literature reveals that if patient care is successful at the end of the working day, the stress that the nurses experienced during the work shift is reported as not being stressful, and the stressor is replaced by a sense of reward and comfort when it is reviewed one hour after the end of the $\operatorname{shift}^{(7)}$.

Salivary cortisol is commonly used as a biomarker to study physiological stress in nurses in international studies $^{(27)}$. The limited use of physiological biomarkers is associated with the high cost of such studies ${ }^{(28)}$.

Comparisons with other studies showed differences in salivary cortisol level on work and days off(29). In the present study, higher values were associated with the salivary cortisol level on work day compared with day off. Although the correlation between salivary cortisol levels and IEE stress score on nurses' work day was not statistically significant, the data from this study indicates that there was a tendency regarding correlation between increased salivary cortisol concentrations and IEE stress scores.

The present study shows that salivary cortisol levels and IEE stress scores were low when measured on nonwork day. Days off are necessary for rest, health maintenance and the well-being of nurses and allow the balance of forces inside the body to be maintained ${ }^{(1)}$.

To date, this study's methodological design is unprecedented in the national literature, which restricts its comparison with other studies. The use of salivary cortisol as a stress biomarker is irrefutable ${ }^{(5)}$. However, a detailed analysis of working conditions and individual needs is required ${ }^{(30)}$, as is the use of other assessment tools such as the identification of stressors during nurses' working hours, ${ }^{(7)}$ because stress perception is unique, and different individuals can experience the same stressors differently.

\section{CONCLUSION}

The use of salivary cortisol levels as a physiological index provided an assessment of the nurses' stress levels, allowed comparisons of stress levels on work and day off and emphasized the difference in stressed experienced at work and on day off.

Thus, the results of this study suggest that on the nurses' day off, stress is less present, as salivary cortisol levels and stress scores were lower. The results indicate that nurses experience stress on their work day.

As a physiological marker, salivary cortisol can concisely identify the presence of stress, and it should be used as a resource for stress identification in nursing work. However, the concomitant use of stress questionnaires is recommended given the importance of psychological research on nurses to identify stressors in their workplace. 


\section{REFERENCES}

1. Silva DMPP, Marziale MHP. Condições de trabalho versus absenteísmo-doença no trabalho de enfermagem. Ciênc Cuidado Saúde. 2008;(5):166-72.

2. Rossi AM. Estressores ocupacionais e diferenças de gênero. In: Rossi AM, Perrewé PL, Sauter SL, organizadores. Stress e qualidade de vida no trabalho: perspectivas atuais de saúde ocupacional. São Paulo: Atlas; 2007. p. 9-18.

3. Nelson DL, Cooper CL. Positive organizational behavior. London: Sage; 2007.

4. Nunes MT. O hipotálamo endócrino. In: Aires MM. Fisiologia. 3a ed. Rio de Janeiro: Guanabara Koogan; 2008. p. 930-51.

5. Hellhammer DH, Wüst S, Kudielka BM. Salivary cortisol as a biomarker in stress research. Psychoneuroendocrinology. 2009;34(2):163-71.

6. Fernandes SMBA, Medeiros SM, Ribeiro LM. Estresse ocupacional e o mundo do trabalho atual: repercussões na vida cotidiana das enfermeiras. Rev Eletr Enferm [Internet]. 2008 [citado 2012 ago.15];10(2):414-27. Disponível em: http://www. fen.ufg.br/revista/v10/n2/v10n2a13.htm

7. Metzenthin P, Helfricht S, Loerbroks A, Terris DD, Haug HJ, Subramanian SV, et al. A one-item subjective work stress assessment tool is associated with cortisol secretion levels in critical care nurses. Prev Med. 2009;48(5):462-6.

8. Stacciarini JMR, Tróccoli BT. Instrumento para mensurar o estresse ocupacional: inventário de estresse em enfermeiros (IEE). Rev Latino Am Enferm. 2000;8(6):40-9.

9. Bianchi ERF. Bianchi Stress Questionnaire. Rev Esc Enferm USP [Internet]. 2009 [cited 2013 Apr 16];43(n. spe):1055-62. http://www.scielo.br/pdf/reeusp/v43nspe/ en_a09v43ns.pdf

10. Kudielka BM, Hellhammer DH, Wüst $\mathrm{S}$. Why do we respond so differently? Reviewing determinants of human salivary cortisol responses to challenge. Psychoneuroendocrinology. 2009;34(1):2-18.

11. Preto VA, Pedrão LJ. Stress among nurses who work at the intensive care unit. Rev Esc Enferm USP [Internet]. 2009 [cited 2012 Sept 10];43(4):841-8. Available from: http://www. scielo.br/pdf/reeusp/v43n4/en_a15v43n4.pdf

12. Conselho Federal de Enfermagem (COFEn), Comissão de Business Intelligence. Produto 2: análise de dados dos profissionais de enfermagem existentes nos Conselhos Regionais [Internet]. Brasília; 2011[citado 2012 set. 20]. Disponível em: http://www.portalcofen.gov.br/sitenovo/sites/default/ files/pesquisaprofissionais.pdf
13. Kunz-Ebrecht SR, Kirschbaum C, Marmot M, Steptoe A. Differences in cortisol awakening response on workdays and weekends in women and men from the Whitehall II cohort. Psychoneuroendocrinology. 2004;29(4):516-28.

14. Thomas C, Hertzman C, Power C. Night work, long working hours, psychosocial work stress and cortisol secretion in mid-life: evidence from a British birth cohort. Occup Environ Med. 2009;66(12):824-31.

15. Stacciarini JM, Tróccoli BT. Occupational stress and constructive thinking: health and job satisfaction. J Adv Nurs 2004;46(5):480-7.

16. Houkes I, Winants YHWM, Twellaar M. Specific determinants of burnout among male and female general practitioners: a cross-lagged panel analysis. J Occup Organ Psychol. 2008;81(2):249-76.

17. Rotenberg L, Portela LF, Banks B, Griep RH, Fischer FM, Landsbergis P. A gender approach to work ability and its relationship to professional and domestic work hours among nursing personnel. Appl Ergon. 2008;39(5):646-52.

18. Eller NH, Netterstrøm B, Hansen AM. Psychosocial factors at home and at work and levels of salivary cortisol. Biol Psychol. 2006;73(3):280-7.

19. Nahm ES, Warren J, Zhu S, An M, Brown J. Nurses' selfcare behaviors related to weight and stress. Nurs Outlook. 2012;60(5):e23-31.

20. Rimmele U, Zellweger BC, Marti B, Seiler R, Mohiyeddini C, Ehlert $U$, Heinrichs $M$. Trained men show lower cortisol, heart rate and psychological responses to psychosocial stress compared with untrained men. Psychoneuroendocrinology. 2007;32(6):627-35.

21. Souza SBC, Tavares JP, Macedo ABT, Moreira PW, Lautert L. Influência do turno de trabalho e cronotipo na qualidade de vida dos trabalhadores de enfermagem. Rev Gaúcha Enferm. 2012;33(4):79-85

22. Pires da Rocha MC, De Martino MMF, Ferreira LRC. Stress of the nurses who work on different hospital departments: a descriptive study. Online Braz J Nurs [Internet]. 2009 [cited 2012 Aug 20];8(3). Available from: http://www.objnursing.uff.br/index.php/nursing/article/ view/2555

23. Guerrer FJL, Bianchi ERF. Caracterização do estresse nos enfermeiros de Unidades de Terapia Intensiva. Rev Esc Enferm USP [Internet]. 2008 [citado 20013 abr. 15];42(2):35562. Disponível em: http://www.scielo.br/pdf/reeusp/ v42n2/v42n2a19.pdf 
24. Grazziano ES, Bianchi ERF. Impacto del estrés ocupacional y burnout en enfermeros. Enferm Global [Internet]. 2010[citado 20013 abr. 15];(18). Disponible en: http://scielo.isciii.es/ pdf/eg/n18/revision1.pdf

25. Guido LA, Linch GFC, Pitthan LO, Umann J. Stress, coping and health conditions of hospital nurses. Rev Esc Enferm USP [Internet]. 2011 [cited 2013 Apr 16];45(6):1434-9. Available from: http://www.scielo.br/pdf/reeusp/v45n6/ en_v45n6a22.pdf

26. Rocha MCP, De Martino MMF. Stress and sleep quality of nurses working different hospital shifts. Rev Esc Enferm USP [Internet]. 2010;44(2):280-6. Available from: http://www. scielo.br/pdf/reeusp/v44n2/en_06.pdf
27. Fujimaru C, Okamura H, Kawasaki M, Kakuma T, Yoshii C, Matsuishi T. Self-perceived work-related stress and its relation to salivary IgA, cortisol and 3-methoxy-4-hydroxyphenyl glycol levels among neonatal intensive care nurses. Stress Health. 2012;28(2):171-4.

28. Adam EK, Kumari M. Assessing salivary cortisol in largescale: epidemiological research. Psychoneuroendocrinology. 2009;34(10):1423-36.

29. Dockray S, Steptoe A. Chronotype and diurnal cortisol profile in working women: Differences between work and leisure days Psychoneuroendocrinology. 2011;36(5):649-55.

30. Silva AA, Rotenberg L, Fischer FM. Jornadas de trabalho na enfermagem: entre necessidades individuais e condições de trabalho. Rev Saúde Pública. 2011;45(6):1117-26. 